\title{
Epidemiological survey on intestinal helminths of stray dogs in Guimarães, Portugal
}

\author{
Vanessa Silva $^{1} \cdot$ Joana Silva $^{1} \cdot$ Margarida Gonçalves $^{1} \cdot$ Carlos Brandão $^{1} \cdot$ \\ Nuno Vieira e Brito ${ }^{2}$ (B)
}

Received: 12 April 2020/ Accepted: 20 July 2020/Published online: 27 July 2020

(C) Indian Society for Parasitology 2020

\begin{abstract}
The new legislative framework on Animal Welfare brought increased responsibilities to municipal shelters, in particular in the collection of stray dogs, their sterilization and future adoption. These centers quickly became overcrowded, leading to high parasitism environmental contamination, to the easy spread of parasitic infections and to increased risks to public health. The prevalence of intestinal parasites was evaluated by examination of dog faecal sample, in the municipal control animal centre of Guimarães (north Portugal), identifying risk factors and transmission to man. The overall prevalence of gastrointestinal helminths was $57.2 \%$ (95\% confidence interval 41.3-71.9\%) and observed helminths of the gastrointestinal tract were recorded: Ancylostoma caninum (33\%), Toxocara canis (29\%), Dipylidium caninum (6\%), Capillaria spp. (3\%), Trichuris vulpis (1.66\%). It is important to point out that young dogs were significantly infected more frequently $(p \leq 0.1)$ than non-sterilized females and the higher occurrence of nematode infection occurred at the new arrival of stray dogs, in the third collection. With impact on public health, the higher prevalence $(p \leq 0.1)$ of $T$. canis in young dogs suggests the existence of real risk for human infection and demonstrate
\end{abstract}

Vanessa Silva, Joana Silva, Margarida Gonçalves, Carlos Brandão and Nuno Vieira e Brito have contributed equally to this work.

Nuno Vieira e Brito

nunobrito@esa.ipvc.pt

1 Polytechnic Institute of Viana do Castelo, 4990-706 Refóios do Lima, Portugal

2 CISAS - Centre for Research and Development in Agrifood Systems and Sustainability, Polytechnic Institute of Viana do Castelo, Viana do Castelo, Portugal the necessity for a parasite control programme reinforcement at the municipal dog shelter.

Keywords Animal shelters $\cdot$ Stray dogs $\cdot$ Nematodes · Risk factors $\cdot$ Public health

\section{Introduction}

Parasitic diseases are often underestimated in the eyes of civil, medical and scientific society, but they are of utmost importance, and comparable to infectious diseases. In Portugal exists an increasing number of stray animals, both in urban and rural areas, where, during 2018, more than 40 thousand stray animals were collected from the streets and, in 2019, in an estimated population of $891.788 \mathrm{dogs}$, only 539.025 were identified and registered (DGAV 2019; FECAVA 2019).

This represent a substantial Public Health risk factor, from an epidemiological point of view, due to the strong environmental contamination of stray dog's feces, without any deworming program and with a high probability of carrying pathogens and parasites, easily transmitted to man. As a potential reservoir of endoparasites, the contamination of public places increases the susceptibility of others animals and humans, in a distressing zoonotic chain (Dado et al. 2012).

"One Health" is a worldwide strategy whose purpose is the expansion of interdisciplinary communications, which link human, animal and environmental health. Not all the mentioned categories are independent and, in fact, parasitism in pets, directly affects the community health, either through direct or environmental contact. It is critical that the control, both of internal and external parasites, occurs 
periodically, avoiding the parasitic zoonosis transmission (Neto and Coelho 2016).

As an animal shelter, the Control Animal Centre (CAC) has an important role in Public Health in the collection of stray animals, in their sterilization, in the implementation of medical and prophylactic control measures, as deworming, and in the promotion of adoption policies. In 2018, the law that forbids the euthanizing of pets due to economic incapacity or overcrowding was enacted (DRE 2019). However, the law brought many inconveniences to the municipalities and the number of stray dogs has been progressively rising, leading to the overpopulation and the reduction of housing conditions. There are, in most cases, several animals living in tiny cages, inducing higher parasitism prevalence (Bresciani et al. 2013), especially when new animals arrive.

In view of the high number of parasites with zoonotic potential, the awareness of the society is extremely important, as well as the correct provision of information to future guardians seeking to adopt animals at the CAC. This lack of information generates great concern, since naivety in relation to the topic promotes an inappropriate use of deworming which, consequently, induces the parasitism resistance and inefficiency in parasite load elimination (Pereira et al. 2016).

The most commonly detected dog parasites of the gastrointestinal tract are Dipylidium caninum, Toxocara canis, Ancylostoma spp., Trichuris vulpis, Taenia spp. and Cystoisospora spp. (Mateus et al. 2014). Although less frequent, Hammondia heydorni and Cryptosporidium spp. are also observed as well as Neospora caninum, a mandatory intracellular protozoan, is frequently found in the blood system (Funada et al. 2007; Taylor et al. 2016).

There are no specific studies about parasitism in stray dogs gathered in official shelters, although a higher prevalence of A. caninum, T. canis, T. vulpis, Cryptosporidium spp. and Strongylidium spp. in Portugal was reported (Silva 2010; Melo and Lebre 2011; Otero et al. 2014). The main objective of this study is to determine the prevalence of gastrointestinal helminthes in stray dogs in Guimarães, with especial attention to potential zoonotic diseases.

\section{Methodology}

\section{Sampling}

This epidemiological study was carried out based on the collection of dog's faecal samples from the Guimarães $\mathrm{CAC}$, a municipal shelter. The CAC has a maximum accommodation capacity of 100 animals and perform the sterilization and the adoption of stray animals. An external and internal deworming plan is established, consisting in the administration of Milbemycin oxime and Praziquantel, in an age frequency dependence.

The study, outlined for 1 year but interrupted by the COVID-19 pandemic, occurred for a period of 3 months, from November 2019 to January, 2020 when the CAC average population was 78 animals. A sample of $25 \%$ of the animals was considered and divided into the three CAC groups: young dogs (under the age of 1 year); sterilized males and females (over the age of 1 year); and non-sterilized females (over the age of 1 year). Feces, 7 samples from each group, were collected every 3 weeks, stored at $4{ }^{\circ} \mathrm{C}$ and processed within $24 \mathrm{~h}$ in the Department Laboratory.

\section{Parasitological procedures}

Fecal samples were first examined for macroscopic observation and, following, faeces were processed using the techniques of concentration by sedimentation (Ritchie 1948) and flotation by centrifugation-flotation (MAFF 1986; Bowman et al. 2004) and counted in a McMaster chamber (Vasconcelos-Nóbrega et al. 2017). Identification of eggs and larvae was based according to the literature keys and guidelines (Yamaguti 1961; Menezes et al. 2013).

\section{Statistical methodology}

Analyses were performed with SPPS $^{\circledR} 22$ software for Windows. Pairwise comparisons between categories of the same independent variable incorporated Bonferroni's correction. A $p$ value $\leq 0.1$ was considered as statistically significant.

\section{Results}

Macroscopic analysis results are presented in Table 1. Only 15 of the 63 total samples presented a non-normal consistency (6 liquids and 9 pasties), and relatively to color, 15 samples had a light brown color, including 6 samples with undigested food particles. No parasites adult forms were observed.

Feces with a pastier consistency were identified (Table 1), more evidently in the third collection and, in particular, in younger animals. In this specific group, was registered color change (light brown) and the presence of poorly digested foods.

Concerning the microscopic analysis (Table 2), several eggs parasitic forms were identified. The overall prevalence of parasitic infection with parasites was 57.2\% [ $(95 \%$ confidence interval (CI) 41.3-71.9\%)] and the most frequently observed parasite was Ancylostoma caninum 


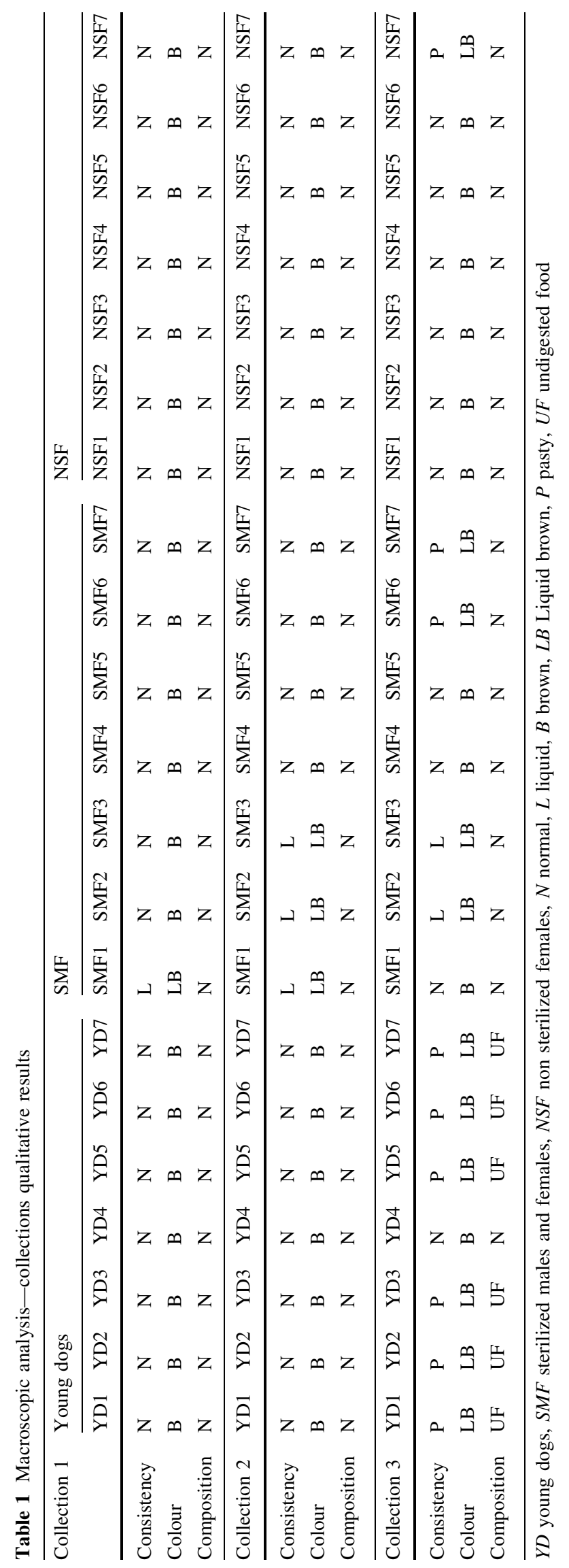


Table 2 Microscopic analysis-quantitative results (faecal eggs count, FEC)

\begin{tabular}{|c|c|c|c|c|c|c|c|c|c|c|c|c|c|c|}
\hline \multirow[t]{2}{*}{ Group } & \multirow[t]{2}{*}{$\mathrm{n}$} & \multirow[t]{2}{*}{$\begin{array}{l}\mathrm{n} / \\
\text { prevalence }\end{array}$} & \multicolumn{2}{|c|}{ Toxocara canis } & \multicolumn{2}{|c|}{$\begin{array}{l}\text { Toxocara canis } \\
\text { (L2) }\end{array}$} & \multicolumn{2}{|c|}{$\begin{array}{l}\text { Ancylostoma } \\
\text { caninum }\end{array}$} & \multicolumn{2}{|c|}{ Cappilaria spp. } & \multicolumn{2}{|c|}{ Trichuris vulpis } & \multicolumn{2}{|c|}{$\begin{array}{l}\text { Dipylidium } \\
\text { caninum }\end{array}$} \\
\hline & & & $\begin{array}{l}\text { Eggs } \\
\text { (FEC) }\end{array}$ & $\begin{array}{l}\mathrm{n} \text { infected } \\
\text { animal/ } \\
\text { prevalence }\end{array}$ & L2 & $\begin{array}{l}\mathrm{n} \text { infected } \\
\text { animal/ } \\
\text { prevalence }\end{array}$ & $\begin{array}{l}\text { Eggs } \\
\text { (FEC) }\end{array}$ & $\begin{array}{l}\mathrm{n} \text { infected } \\
\text { animal/ } \\
\text { prevalence }\end{array}$ & $\begin{array}{l}\text { Eggs } \\
\text { (FEC) }\end{array}$ & $\begin{array}{l}\mathrm{n} \text { infected } \\
\text { animal/ } \\
\text { prevalence }\end{array}$ & $\begin{array}{l}\text { Eggs } \\
\text { (FEC) }\end{array}$ & $\begin{array}{l}\mathrm{n} \text { infected } \\
\text { animal/ } \\
\text { prevalence }\end{array}$ & $\begin{array}{l}\text { Eggs } \\
\text { (FEC) }\end{array}$ & $\begin{array}{l}\mathrm{n} \text { infected } \\
\text { animal/ } \\
\text { prevalence }\end{array}$ \\
\hline YD1 & 7 & $\begin{array}{l}4 \\
57.10\end{array}$ & $\begin{array}{l}- \\
-\end{array}$ & - & - & - & 4 & $\begin{array}{l}4 \\
57.10\end{array}$ & - & - & - & - & - & - \\
\hline YD2 & 7 & $\begin{array}{l}7 \\
100\end{array}$ & 205 & $\begin{array}{l}7 \\
100\end{array}$ & - & - & 1 & $\begin{array}{l}1 \\
14.28\end{array}$ & - & - & - & - & - & - \\
\hline YD3 & 7 & $\begin{array}{l}6 \\
86\end{array}$ & 18 & $\begin{array}{l}3 \\
43.00\end{array}$ & - & - & 1146 & $\begin{array}{l}6 \\
86\end{array}$ & 1 & $\begin{array}{l}1 \\
14.30\end{array}$ & 1 & $\begin{array}{l}1 \\
14.30\end{array}$ & 95 & $\begin{array}{l}1 \\
14.30\end{array}$ \\
\hline SMF1 & 7 & $\begin{array}{l}2 \\
28.60\end{array}$ & 1 & $\begin{array}{l}1 \\
14.30\end{array}$ & - & - & 4 & $\begin{array}{l}2 \\
28.60\end{array}$ & - & - & - & - & - & - \\
\hline SMF2 & 7 & $\begin{array}{l}4 \\
57.10\end{array}$ & 19 & $\begin{array}{l}2 \\
28.60\end{array}$ & - & - & 3 & $\begin{array}{l}2 \\
28.60\end{array}$ & - & - & - & - & - & - \\
\hline SMF3 & 7 & $\begin{array}{l}5 \\
71.40\end{array}$ & 4 & $\begin{array}{l}1 \\
14.28\end{array}$ & - & - & 100 & $\begin{array}{l}3 \\
42.84\end{array}$ & - & - & - & - & 223 & $\begin{array}{l}2 \\
28.60\end{array}$ \\
\hline NSF1 & 7 & $\begin{array}{l}2 \\
28.60\end{array}$ & 33 & $\begin{array}{l}1 \\
14.30\end{array}$ & 2 & $\begin{array}{l}1 \\
14.30\end{array}$ & 16 & $\begin{array}{l}1 \\
14.30\end{array}$ & - & - & - & - & $\begin{array}{l}- \\
-\end{array}$ & - \\
\hline NSF2 & 7 & $\begin{array}{l}4 \\
57.10\end{array}$ & 8 & $\begin{array}{l}2 \\
28.60\end{array}$ & - & - & 1 & $\begin{array}{l}1 \\
14.30\end{array}$ & 1 & $\begin{array}{l}1 \\
14.30\end{array}$ & - & - & & - \\
\hline NSF3 & 7 & $\begin{array}{l}2 \\
28.60\end{array}$ & 6 & $\begin{array}{l}1 \\
14.30\end{array}$ & - & - & 21 & $\begin{array}{l}1 \\
14.30\end{array}$ & - & - & - & - & 11 & $\begin{array}{l}1 \\
14.30\end{array}$ \\
\hline
\end{tabular}

$Y D$ young dogs, $S M F$ sterilized males and females, $N S F$ non sterilized females

(33\%), followed by Toxocara canis (29\%) and Dipylidium caninum $(6 \%)$.

In line with the macroscopic analysis results, an important increase in parasitism in the third collection was verified, particularly in younger animals (86\% prevalence), but also in sterilized ones ( $71.4 \%$ prevalence). At this third sampling, A. caninum (present in all samples) and $T$. canis revealed a higher prevalence ( $86 \%$ and $43 \%$, respectively), in terms of group and/or reproductive status.

In addition to the high parasite load verified (particularly, A. caninum 1146 FEC) in the third collection, the presence of eggs of Trichuris vulpi (1FEC), Capillaria spp. (1FEC) and D. caninum were identified also mainly in young dogs. The presence of $D$. caninum (329 FEC) was observed, only in this collection, in all groups analyzed, but particularly in sterilized animals (29\% prevalence). Regarding the first collection, a second-form L2 larvae of $T$. canis was identified in the group of non-sterilized females. Also in this group, but in the second collection, eggs of Capillaria spp. were observed in a small infestation (1FEC).

The mean and standard deviation parasite load values (FEC) obtained by group and collection are observed in Fig. 1, stressing the high values verified in the youngest animals and third collection, comparing to the lowest levels of adult animals' infestation (sterilized or not), with the exception of the third SMF sample.

Significant differences $(p \leq 0.1)$ were found among collections (Table 3), with higher values between the third (73.190 FEC), the first (2.143 FEC) and the second (10.762 FEC) collection, as well as groups with higher $(p \leq 0.1)$ parasite load value in the youngest (66.81 FEC) comparing to the NSF (3.38 FEC).

The average values (FEC) per group, were estimated and higher parasite load of T. canis (10.62 \pm 15.66 FEC) and D. caninum (55 \pm 156.57 FEC) was found in younger animals while A. caninum (4.52 \pm 20.271 FEC) showed higher levels in sterilized animals. T. canis also presented significant differences between groups $(p \leq 0.05)$, with a superior infestation $(10 \times)$ in the youngest animals $(10.62$ FEC) comparing to the sterilized (1.14 FEC) and nonsterile (1.71) groups.

\section{Discussion}

Natural transmission of parasitic infections from dogs to man may occur, directly or indirectly, via environmental factors and represent a potential public health risk, particularly to individuals with close contact with those animals 
Fig. 1 Mean parasite load (FEC), considering group and collection

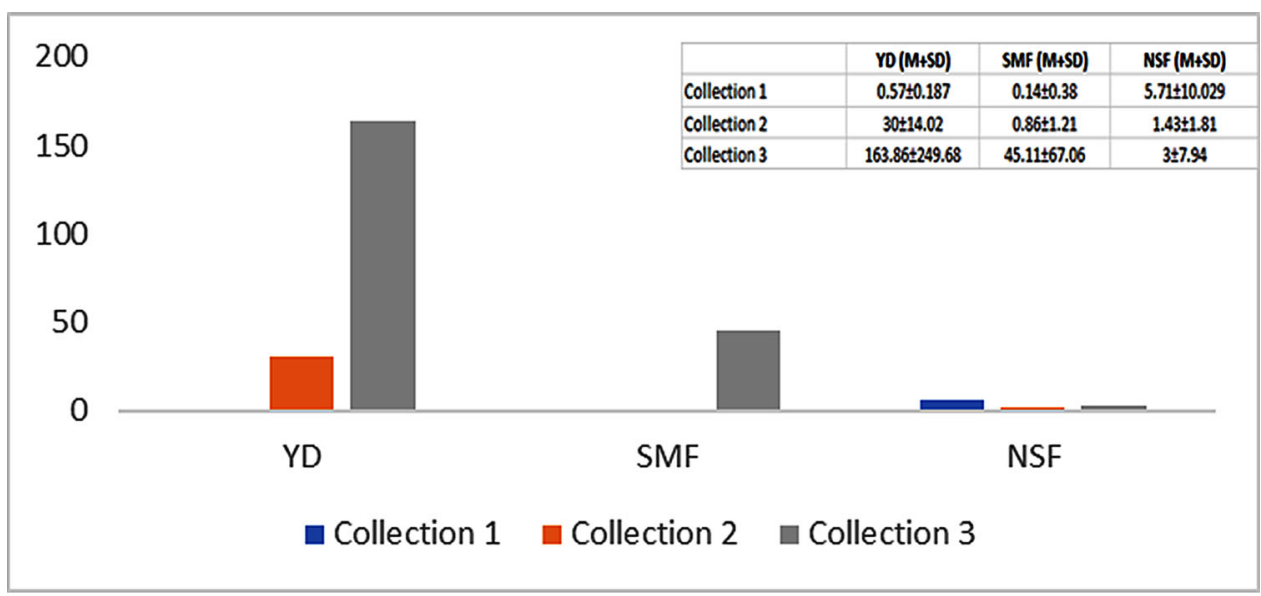

Table 3 Statistic mean differences $(p \leq 0.1)$ between collections and groups

\begin{tabular}{|c|c|c|c|c|c|c|c|c|c|c|c|c|c|}
\hline \multicolumn{3}{|c|}{$\begin{array}{l}\text { (i) Collection/ } \\
\text { mean (FEC) }\end{array}$} & \multirow[t]{2}{*}{$\begin{array}{l}\text { Difference of means } \\
(\mathrm{I}-\mathrm{J})\end{array}$} & \multirow[t]{2}{*}{ Sig. } & \multicolumn{2}{|c|}{$\begin{array}{l}\text { Confidence interval } \\
90 \%\end{array}$} & \multicolumn{3}{|c|}{$\begin{array}{l}\text { (ii) Group/mean/ } \\
\text { FEC) }\end{array}$} & \multirow[t]{2}{*}{$\begin{array}{l}\text { Difference of means } \\
(\mathrm{I}-\mathrm{J})\end{array}$} & \multirow[t]{2}{*}{ Sig. } & \multicolumn{2}{|c|}{$\begin{array}{l}\text { Confidence interval } \\
90 \%\end{array}$} \\
\hline & & & & & $\begin{array}{l}\text { Lower } \\
\text { limit }\end{array}$ & $\begin{array}{l}\text { Upper } \\
\text { limit }\end{array}$ & & & & & & $\begin{array}{l}\text { Lower } \\
\text { limit }\end{array}$ & $\begin{array}{l}\text { Upper } \\
\text { limit }\end{array}$ \\
\hline \multirow[t]{2}{*}{ Dec } & 10.76 & Jan & $-62.43^{*}$ & 0.059 & -126.69 & 1.84 & NSF & 3.38 & SMF & -12.52 & 0.89 & -68.44 & 43.39 \\
\hline & & Nov & 8.62 & 0.944 & -55.65 & 72.89 & & & YD & $-63.43^{*}$ & 0.05 & -119.34 & -7.51 \\
\hline \multirow[t]{2}{*}{ Jan } & 73.19 & Dec & $62.43^{*}$ & 0.059 & 1.84 & 126.7 & SMF & 15.91 & NSF & 12.52 & 0.89 & -43.39 & 68.44 \\
\hline & & Nov & $71.05^{*}$ & 0.027 & 6.78 & 135.31 & & & YD & 50.9 & 0.15 & -106.82 & 5.01 \\
\hline \multirow[t]{2}{*}{ Nov } & 2.14 & Dec & -8.62 & 0.944 & -72.89 & 55.65 & YD & 66.81 & NSF & $63.43^{*}$ & 0.05 & 7.51 & 119.34 \\
\hline & & Jan & $-71.05^{*}$ & 0.027 & -135.31 & -19.3 & & & SMF & 50.9 & 0.15 & -5.01 & 106.82 \\
\hline
\end{tabular}

*Difference of means significant on level 0.10

(Martínez-Moreno et al. 2007). CAC are an important indicator for the evaluation of regional parasite prevalence and, consequently, develop a relevant role in animal and public health.

The overall prevalence of intestinal parasitosis found in this study is $57.2 \%$, revealing a considerable presence of gastrointestinal parasites in stray and shelters dogs, compared to the lower prevalence values observed in other Europeans countries (Pullola et al. 2006; Becker et al. 2012; Dado et al. 2012; Zanzani et al. 2014). Similar values $(54.3 \%)$ were found by Katagiri and Oliveira-Sequeira (2008) in stray and domiciled dogs in Brasil, also in stray dogs in Nigeria (52.6\%, Okoye et al. 2011), Malaysia (48\%, Mahdy et al. 2012) and Canada (21\%, Joffe et al. 2011). Higher prevalence was reported, in stray dogs, in Iran (86\%, Emamapour et al. 2015), México (85\%, EguíaAguilar et al. 2005), South Africa (76\%, Minner et al. 2002), Spain (71\%, Martínez-Carrasco et al. 2007) and Poland (68\%, Bajera et al. 2011).

Our results indicate the requirement, in the official dog shelters, of an effective anti-parasite control programme, due to the continuous collection of stray dogs, with no health control measures and, because of their habits, exposed to natural infections. Shelter dogs are exposed to a greater parasite load, to less effective anti-parasite treatments, and have a poorer nutritional status. This implies a change in shelter's routine, such as the entry of new animals, particularly pups, which has a direct influence on the increase in the parasite load and requires more frequent hygiene and prophylaxis measures, as quarantine or deworming.

Pups are infected by vertical transmission, transplacental and/or trans-mammary as well as horizontal transmission through the ingestion of embryonated eggs from the environment or ingestion of larvae via vertebrate and/or invertebrate paratenic hosts (Overgaauw and van Knapen 2013). The $T$. canis trans-placental infection route results in egg excretion 16 days after parturition and lactogenic transmission, more limited, continues to occur for 5 weeks, shedding, after infection, millions of eggs per day into the environment (Lloyd and Morgan 2011).

In fact, parasitic infections were observed specially in the third collection, in young animals that had recently arrived and were dewormed, revealing a severe 
environmental contamination with a higher risk of zoonotic transmission from dogs. Given this prevalence in pups, specific interventions with a focus in animal birth control, parasites control programs and public education to take wise action relating to the parasites and pets, need to be reinforced. Moreover, animal shelters facilitate spread of gastrointestinal parasites to incoming animals and shelter staff if there is overcrowding and frequent exposure to a contaminated environment (Raza et al. 2018).

According to similar results in different studies, the most prevalent species observed were A. caninum, and $T$. canis, widely known as potential zoonotic agents (Emamapour et al. 2015; Cociancic et al. 2018; Suganya et al. 2019). A. caninum is the primary hookworms' specie infecting dogs worldwide (Traversa et al. 2014). Hookworms may occur in dogs of all ages, independently of sex or season (Coggins 1998), even when under regular control programs (Sager et al. 2006), as verified in our study, where no significant difference were obtained between groups.

The zoonotic importance of A. caninum, a historical association of humans, dogs and hookworms, resides in that its larvae survive in the environment for several months (Shepherd et al. 2018). Adult dogs can become infected with environmental larvae or when hypobiotic stages are re-activated by drivers of stress (Bowman et al. 2004). Hypobiotic larvae may survive for years in the tissues of adult dogs and when reactivated during oestrus and in the last 2-3 weeks of pregnancy, transmitted via milk to the litter (Little et al. 2009; Traversa et al. 2014).

Although has been decreased significantly over time, presumably due to routine use of broad-spectrum anthelmintics, T. canis is the primary roundworm specie infecting dogs worldwide (Robertson and Thompson 2002). Eggs of T. canis are very resistant and can withstand harsh environmental conditions and is estimated that Toxocara eggs contamination soil may be more than the $90 \%$ of the investigated areas worldwide (Kirchheimer and Jacobs 2008).

T. canis is more prevalent in puppies and can be fatal, especially when there is heavy prenatal infection (Overgaauw 1997). Pups are infected in utero by reactivated somatic larvae of $T$. canis from the mother from day 42 of gestation resulting in egg excretion $\sim 16$ days after parturition (Traversa et al. 2014). Puppies can also be infected through the transmammary route (Robertson and Thompson 2002). Once infected, pups shed millions of eggs per day into the environment, depending on the intensity of $T$. canis infection and host immune status (Glickman and Schantz 1981).

In our study, significant differences were observed between young and adult dogs infected with $T$. canis. These results are consistent with other findings revealing that adult worm infections are generally less common in dogs with less than 6 months of age, and that faecal egg counts are much lower than in pups (Papazahariadou et al. 2007; Xhaxhiu et al. 2011).

D. caninum is the most common cestode in the world, especially in dogs, frequently infested by fleas and biting lices and with a higher prevalence in adult animals (Raza et al. 2018). Humans can become infected and very young children are the ones most often affected, associated with diarrhea and abdominal pain (Molina et al. 2003). The prevalence observed in this study is significantly lower than in others reported by different authors (Xhaxhiu et al. 2011; Emamapour et al. 2015) and was verified in all ages but only in the third collection, what can be attributed to an infestation by the eventual entry of new stray dogs.

Zoonotic parasitosis is a serious public health problem and parasitism in stray and shelter dogs is a relevant indicator of, both, the deficiencies in the sanitary and ecological conditions of their hosts, of the socio-environmental conditions and hygiene practices of the population (Cociancic et al. 2018). In order to reduce environmental contamination and parasitism in the shelter, the implementation of sanitation measures is mandatory, such as quarantine of new stray dogs collected or more regular faecal examination, and the appropriate use, particularly in terms of dose and frequency, of deworming agents, according to the animal's weight and the shelter parasitic load (Raza et al. 2018). Anthelmintic therapy should be accompanied by flea control programs to minimize transmission of D. caninum (Taylor et al. 2016).

The full development of our study was compromised by the COVID-19 pandemic, as it had the objective of lasting 1 year, evaluating diverse factors with influence on parasitism. The data about type and parasitic load and its influence in the community, are required to the implementation of public health policies, with the support of the veterinary health authorities.

Acknowledgements The authors are grateful to all the Guimarães Municipality and CAC collaborators, in particular to the VMD MSc Guida Brito, for providing necessary research facilities to carry out this work, especially in the sample collections and animal's handling. We also want to extend our thanks to Ms. Andreia Silva for the technical and laboratory support. To VMD MSc Elsa Machado, from Food and Veterinary General Directorate, our gratitude to the continuous support and incentive of this research.

Author's contribution All authors contributed to the study conception and design. Collection samples and identification of the parasites were done by Vanessa Silva and Margarida Gonçalves, data analysis were performed by Joana Silva, Carlos Brandão. The first draft of the manuscript was written by Vanessa Silva. Carlos Brandão and Nuno Vieira e Brito reviewed the article. All authors read and approved the final manuscript.

Funding Not applicable. 


\section{Compliance with ethical standards}

Conflict of interest None of the authors has any financial or personal relationships that could inappropriately influence or bias the content of the paper.

Ethical approval Not applicable. Authors were not involved with animal handling and the fecal samples were obtained directly through the shelter staff, specifically from the veterinary shelter authority.

\section{References}

Bajera A, Bednarskaa M, Rodob A (2011) Risk factors and control of intestinal parasite infections in sled dogs in Poland. Vet Parasitol 175(3-4):343-350

Becker AC, Rohen M, Epe C, Schnieder T (2012) Prevalence of endoparasites in stray and fostered dogs and cats in Northern Germany. Parasitol Res 111:849-857

Bowman DD, Lynn RC, Eberhard ML (2004) Parasitología para veterinarios, $8^{\mathrm{a}}$ edn. Elsevier Science, Madrid

Bresciani KS, Aquino MC, Zucatto AS, Inácio SV, Neto LS, Coelho ND, Coelho WD, Brito RL, Viol MA, Meireles MV (2013) Criptosporidiose em animais domésticos: aspetos epidemiológicos. Ciênc Agrár 34(5):2387-2402. https://doi.org/10.5433/ 1679-0359.201

Cociancic P, Zonta ML, Navone GT (2018) A cross-sectional study of intestinal parasitoses in dogs and children of the periurban área of La Plata (Buenos Aires, Argentina): zoonotic importance and implications in public health. Zoonoses Public Health 65(1):44-53

Coggins JR (1998) Effect of season, sex, and age on prevalence of parasitism in dogs. J Helminthol Soc Wash 65:219-224

Dado DI, Izquierdo F, Vera O, Montoya A, Mateo M, Fenoy S, Galván AL, García S, García A, Aránguez E, López L, del Águila C, Miró G (2012) Detection of zoonotic intestinal parasites in public parks of Spain. potential epidemiological role of microsporidia. Zoonoses Public Health 59(1):23-28. https://doi.org/10.1111/j.1863-2378.2011.01411

DGAV (2019) Número de Animais e Explorações/Detentores-Portugal. Direção Geral de Alimentação e Veterinária. http://www. dgv.min-agricultura.pt/portal/page/portal/DGV. Accessed 20 Feb 2020

DRE (2019) Decreto Lei ${ }^{\circ}$ 161/2016 de 2016-08-23. Diário da República: Série I. Site disponível: Diário da Republica Eletrónico. https://data.dre.pt/eli/diario/1/161/2016/0/pt/html. Accessed 20 Feb 2020

Eguía-Aguilar P, Cruz-Reyes A, Martinez-Maya JJ (2005) Ecological analysis and description of the intestinal helminths present in dogs in Mexico City. Vet Parasitol 127:139-146

Emamapour SR, Borji H, Nagibi A (2015) An epidemiological survey on intestinal helminths of stray dogs in Mashhad, North-east of Iran. J Parasit Dis 39(2):266-271. https://doi.org/10.1007/s12639-013-0319-0

FECAVA (2019) Promovendo a liderança da classe médico veterinária relativamente ao controlo de cães errantes na Europa. Federation of European Companion Animal Veterinary Associations. https://www.apmveac.pt/admin/modulo_pages/upload/files/ traduo_posio_FECAVA_sobre_ces_errantes.pdf. Accessed 12 Feb 2020

Funada MR, Pena HJ, Soares RM, Amaku M, Gennari SM (2007) Frequência de parasitos gastrointestinais em cães e gatos atendidos em hospital-escola veterinário da cidade de São Paulo. Arq Bras Med Vet Zootec 59(5):1338-1340
Glickman L, Schantz P (1981) Epidemiology and pathogenesis of zoonotic toxocariasis. Epidemiol Rev 3(1):230-250. https://doi.org/10.1093/oxfordjournals.epirev.a036235

Joffe D, Van Niekerk D, Gagne F, Gilleard J, Kutz S, Lobingier R (2011) The prevalence of intestinal parasites in dogs and cats in Calgary, Alberta. Can Vet J 52:1323-1328

Katagiri S, Oliveira-Sequeira TC (2008) Prevalence of dog intestinal parasites and risk perception of zoonotic infection by dog owners in São Paulo State, Brazil. Zoonoses Public Health 55(8-10):406-413. https://doi.org/10.1111/j.1863-2378.2008.01163

Kirchheimer R, Jacobs DE (2008) Toxocara species egg contamination of soil from children's play areas in southern England. Vet Rec 163(13):394-395. https://doi.org/10.1136/vr.163.13.394

Little SE, Johnson EM, Lewis D, Jaklitsch RP, Payton ME, Blagburn BL, Bowman DD, Moroff S, Tams T, Rich L, Aucoin D (2009) Prevalence of intestinal parasites in pet dogs in the United States. Vet Parasitol 166(1-2):144-152

Lloyd S, Morgan ER (2011) Toxocarosis. In: Palmer SR, Soulsby L, Torgerson PR, Brown DWG (eds) Zoonoses: biology, clinical practice and public health control, 2nd edn. Oxford University Press, Oxon, pp 787-797

MAFF (1986) Manual of veterinary parasitological techniques, 3rd edn. Her Majesty's Stationery Office, London

Mahdy MA, Lim YA, Ngui R, Siti Fatimah MR, Choy SH, Yap NJ, Al-Mekhlafi HM, Ibrahim J, Surin J (2012) Prevalence and zoonotic potential of canine hookworms in Malaysia. Parasites Vectors 5:88

Martínez-Carrasco C, Berriatua E, Garijo M, Martínez J, Alonso FD, Ruiz de Ybánez R (2007) Epidemiological study of nonsystematic parasitism in dogs in southeast Mediterranean Spain assessed by coprological and post-mortem examination. Zoonoses Public Health 54(5):195-203

Martínez-Moreno FJ, Hernández S, López-Cobos E, Becerra C, Acosta I, Martínez-Moreno A (2007) Estimation of canine intestinal parasites in Cordoba (Spain) and their risk to public health. Vet Parasitol 143(1):7-13

Mateus T, Castro A, Ribeiro J, Vieira-Pinto M (2014) Multiple zoonotic parasites identified in dog feces collected in Ponte de Lima, Portugal - a potential threat to human health. Int J Environ Res Public Health 11(9):9050-9067

Melo FL, Lebre CR (2011) Rastreio de parasitas gastrointestinais e seu impacto zoonótico em cães de canil na cidade de Lisboa (Unpublised doctoral dissertation). Universidade Técnica de Lisboa- Faculdade de Medicina Veterinária, Portugal

Menezes RO, Gomes MS, Barbosa FH, Machado RD, Andrade RF, Couto AR (2013) Sensibilidade de métodos parasitológicos para diagnóstico das enteroparasitoses em Macapá-Amapá, Brasil. Rev Biol Ciênc Terra 13(2):1-8

Minner WN, Krecek RC, Fourie LJ (2002) Helminths in dogs from a peri-urban resource-limited community in free State Province, South Africa. Vet Parasitol 107(4):343-349

Molina CP, Ogburn J, Adegboyega P (2003) Infection by Dipylidium caninum in an infant. Arch Pathol Lab Med 127(3):157-159

Neto G, Coelho AC (2016) Importância do médico veterinário no conhecimento dos proprietários de pequenos animais sobre zoonoses numa perspetiva da "One Health" em Portugal. Rev Eletrón Vet 17(7):1-13

Okoye IC, Obiezue NR, Okorie CE, Ofoezie IE (2011) Epidemiology of intestinal helminth parasites in stray dogs from markets in south-eastern Nigeria. J Helminthol 85(4):415-420. https://doi.org/10.1017/S0022149X10000738

Otero D, Nijsse R, Gomes L, Alho A, Overgaauw P, Hoek D, Carvalho LM (2014) Prevalência de ovos de Toxocara spp. no solo de parque públicos da área da grande Lisboa, PortugalResultados preliminares, Portugal. Acta Parasitol Port 20(1/ 2):47-50 
Overgaauw PA (1997) Aspects of Toxocara epidemiology: Toxocarosis in dogs and cats. Crit Rev Microbiol 23(3):233-251

Overgaauw PA, van Knapen F (2013) Veterinary and public health aspects of Toxocara spp. Vet Parasitol 193:398-403

Papazahariadou M, Founta A, Papadopoulos E, Chliounakis S, Antoniadou-Sotiriadou K, Theodorides Y (2007) Gastrointestinal parasites of shepherd and hunting dogs in the Serres Prefecture, Northern Greece. Vet Parasitol 148:170-173. https://doi.org/10.1016/j.vetpar.2007.05.013

Pereira A, Martins A, Brancal H, Vilhena H, Silva P, Pimenta P, Lopes-Diz D, Neves N, Coimbra M, Alves AC, Cardoso L, Maia C (2016) Parasitic zoonosesassociated with dogs and cats: a survey of Portuguese pet owner's awareness and deworming practices. Parasites Vectors 9(245):1-9

Pullola T, Vierimaa J, Saari S, Virtala AM, Nikander S, Sukura A (2006) Canine intestinal helminths in Finland: prevalence, risk factors and endoparasite control practices. Vet Parasitol 140(3-4):321-326

Raza A, Rand J, Qamar AG, Jabbar A, Kopp S (2018) Gastrointestinal parasites in shelter dogs: occurrence, pathology, treatment and risk to shelter workers. Animals (Basel) 8(7):108

Ritchie LS (1948) An ether sedimentation technique for routine stool examination, Bulletin of the United States Army Medical Department, vol 8, no 4, p 326

Robertson ID, Thompson RC (2002) Enteric parasitic zoonoses of domesticated dogs and cats. Microbes Infect 4(8):867-873

Sager H, Moret CS, Grimm F, Deplazes P, Doherr MG, Gottstein B (2006) Coprological study on intestinal helminthes in Swiss dogs: temporal aspects of anthelmintic treatment. Parasitol Res 98:333-338. https://doi.org/10.1007/s00436-005-0093-8

Shepherd C, Wangchuk P, Loukas A (2018) Of dogs and hookworms: man's best friend and his parasites as a model for translational biomedical research. Parasites Vectors 11:59. https://doi.org/ 10.1186/s13071-018-2621-2
Silva MS (2010) Rastreio de parasitas gastrointestinais, pulmonares, cutâneos e musulares em canídeos domésticos e silvestres no norte de Portugal. (Unpublised doctoral dissertation). Universidade Técnica de Lisboa-Faculdade de Medicina Veterinária, Portugal

Suganya G, Porteen K, Sekar M, Sangaran A (2019) Prevalence and molecular characterization of zoonotic helminths in dogs. J Parasit Dis 43(1):96-102. https://doi.org/10.1007/ s12639-018-1066-z

Taylor M, Coop R, Wall R (2016) Veterinary parasitology, $4^{\mathrm{a}}$ edn. Wiley-Blackwell, London

Traversa D, Regalbono AF, Di Cesare FT, Drake J, Pietrobelli M (2014) Environmental contamination by canine geohelminths. Parasites Vectors 7:67

Vasconcelos-Nóbrega C, Santos C, Mega C, Coelho C, Cruz R, Vala $\mathrm{H}$, Esteves F, Mesquita JR (2017) ABC series on diagnostic parasitology part 2: the McMaster method. Vet Nurse 8(8):458-462

Xhaxhiu D, Kusi I, Rapti D, Kondi E, Postoli R, Rinaldi L, Dimitrova ZM, Visser M, Knaus M, Rehbein S (2011) Principal intestinal parasites of dogs in Tirana, Albania. Parasitol Res 108:341-353

Yamaguti S (1961) Systema helminthum, the nematodes of vertebrates, 3rd edn. Interscience Publishers, New York

Zanzani SA, Gazzonis AL, Scarpa P, Berrilli F, Manfredi MT (2014) Intestinal parasites of owned dogs and cats from metropolitan and micropolitan areas: prevalence, zoonotic risks, and pet owner awareness in northern Italy. Biomed Res Int 2014:1-10. https://doi.org/10.1155/2014/696508

Publisher's Note Springer Nature remains neutral with regard to jurisdictional claims in published maps and institutional affiliations. 